\title{
Teachers Teaching Management During Belajar dari Rumah (BDR) Policy in Higher Education: A Piece of Teacher Sharing Ways
}

\author{
Suryawahyuni Latief ${ }^{1}$, Santi Hendrayani ${ }^{2}$, Samsuddin ${ }^{3}$ \\ ${ }_{123}$ Universitas Nurdin Hamzah Jambi, Indonesia
}

niniek_yuni@yahoo.com

\begin{abstract}
Teaching is an educator activity in the learning process, which aims to develop the potential that students have in the form of knowledge, skills, and attitudes. Since the Covid 19 pandemic, the government has issued a policy of "Belajar Dari Rumah" (BDR) as an effort to overcome the spread of the virus. Teaching in accordance with BDR policy makes educators at private universities in Jambi city who do not have a Learning Management System (LMS) conduct teaching management in accordance with their expertise and knowledge. This study aims to describe the experience of educators in universities who do not have LMS in managing teaching during the Covid 19 pandemic so that learning can run according to learning objectives using a qualitative descriptive approach, involving ten educators with different scientific fields and courses. This research uses a qualitative research method involving ten educators from private universities in Jambi who do not have LMS. Data have collected through observations, interviews, and documents. The data collected have analyzed through the stages of reducing data, displaying data, and drawing conclusions in accordance with research objectives. The data analyzed is using the technique validity of data through data triangulation. The study found that the management of educator teaching in private universities in Jambi city who do not have LMS is implemented BDR policies during the pandemic period following the established implementation rules without leaving the meaning of learning and learning process standards that have set out in government regulations through the stage of teaching management.
\end{abstract}

Keywords: Work from Home, Belajar dar Rumah, Teaching Management

How to cite

Latief, S., Hendrayani, S., \& Samsudin, S. (2021). Teachers Teaching Management During “Belajar Dari Rumah (Bdr)" Policy In Higher Education: A Piece of Teacher Sharing Ways. IJoASER (International Journal on Advanced Science, Education, and Religion), 4(1). 9-18.89

https://doi.org/10.33648/ijoaser.v4i1.

Journal Homepage https://ojs.staialfurqan.ac.id/IJoASER/

This is an open access article under the CC BY SA license

https://creativecommons.org/licenses/by-sa/4.0/

\section{INTRODUCTION}

The task of an educator in higher education is transforming the science and/or technology their mastered to students by realizing the atmosphere of learning and learning so that students actively develop their potential. This task often referred to as teaching according to the area of expertise of each educator. Based on Law No. 12 of 2012, in teaching an educator must have the competence to realize a learning atmosphere that can encourage student activities. 
Learning in higher education according to Regulation of the Ministry of education and culture No.3 of 2020 article 1 of the National Standard of Higher Education is the process of student interaction with lecturers and learning resources in the learning environment unit in accordance with the established learning process standards. Learning Process Standard is minimum criteria for the implementation of learning in a study program to obtain graduate learning achievements according to Ministry of education and culture regulation No. 3 of 2020 consists of:

1. Characteristics of the learning process are interactive, holistic, integrative, scientific, contextual, thematic, effective, collaborative and student-centered;

2. Planning the learning process, which is arranged in the form of a semester learning plan, which is determined by lecturers independently or together in a field of expertise groups;

3. The implementation of the learning process carries out in the form of interaction between lecturers, students, and learning resources in a certain learning environment that carries out in accordance with the semester learning plan.

Furthermore, Ministerial Regulation No. 3 of 2020 states that learning methods carried out in higher education include group discussions, simulations, case studies, cooperative learning, project-based learning, problem-based learning or other methods that can effectively meet graduate learning achievements. Lecturers can combine several methods mentioned in the implementation of learning activities in the classroom.

The Covid 19 pandemic spread around the world in early 2020 resulting in the emergence of new policies in various sectors of life to overcome the spread of the virus. In the education sector, the Government of Indonesia issued Learning from Home, namely Belajar Dari Rumah (BDR) policy through the circular of the Minister of Cultural Education (CoMEC) number 4 of 2020 and the guidelines for the implementation of BDR in the circular of the secretary general number 15 of 2020. The purpose of BDR policy is to fulfill the rights of learners in education services during the Covid 19 pandemic. The implementation of BDR policy in the form of online, semionline, and off-network distance learning methods that is depending on the situation and condition of each region.

Teaching during the pandemic in accordance with government policy, is a new experience for educators because teaching activities undergo a change from activities carried out in the classroom to a virtual space. Teaching is an activity that involves various sources so that learning objectives achievement. Teaching in universities according to Goodyear (2015), states that teaching consists of three activities, namely interactive teaching, namely students and educators working together at the same time, followed by activities according to teaching planning made by educators followed by evaluation and reflection activities. Furthermore, Goodyear (2015) highlighted that teaching in higher education needs to address in the right way not only on lesson planning, but also in learning design.

Teaching is an educator activity in providing learning in the form of knowledge and skills to improve students' abilities through learning activities (Kusumaningrum, et al., 2019; Lock, 2017; Teach \& Govahi 1993). Teaching is a purposeful teaching and part of the management of the teaching and learning process. Teaching management is an activity of educators in managing learning activities in accordance with instructional objectives and educational objectives. Management according to 
Taylor (1967) is the art of knowing what you want to do and then seeing that they do it in the best and the cheapest way. Terry (2009) defines management as a process consisting of several stages, namely planning, organizing, implementing, and controlling with knowledge and art in order to achieve the goals that have been set. Latief (2018) define management as an art and science to manage an activity through existing resources in order to achieve goals effectively and efficiently. Management with regard to the responsibility to carry out, carry out, direct, and control an activity within a set framework (Clegg, et al., 2016).

In conducting teaching management, teacher involves management functions in the form of planning, organizing, implementing, and controlling (Terry, 2009). Shaikh (2010) presents teaching management as follows:

1. Planning with regard to what to do, when to do, and who to do so that activities can be properly resolved;

2. Organizing is to build relationships between the activities carried out, the individuals who carry out and other factors that support in accordance with the plan that has been made;

3. Briefing is an activity carried out so that the planning made can be carried out;

4. Controlling helps to prevent the planning implementation, and to minimize the failure of planned activities.

Related to the management of teaching educators, scholars conduct research on teaching management systems that are available in universities in the form of learning management systems (LMS) based on learning models (Lopes, 2011; Kotzert, S., \& Eiran, 2012; Eli, H., \& Arntzen, 2013). Furthermore, Ali and Camp (1995) examined the management of teaching in Arabia regarding growth problems, low quality and lack of vision for the future.

According to Wikipedia website, LMS is a software application used to carry out online activities, electronic learning, and training. This system used as a media for virtual learning to facilitate the teaching process. For higher education that already has a learning management Systems (LMS), BDR policy can manage well. However, in colleges that do not yet have LMS, this policy requires good management of each educator. The purpose of this research is to describe the experience of educators in universities who do not have LMS in managing teaching during the Covid 19 pandemic so that learning can run according to learning objectives.

The difference of research conducted by the authors today with previous research is located in the focus of research conducted. The previous research focused on the management of teaching educators in universities that have used LMS, while in this study focused on the management of teaching educators in universities that do not have LMS in pandemic conditions in accordance with policies issued by the government. This is very necessary to review considering that, BDR policy is a government policy that is directly implemented, and is a new thing for educators in universities who do not have LMS. Therefore, it is a new experience for educators to conduct learning in accordance with BDR policies through the management of teaching. This research provides an overview of the management of teaching educators in carrying out BDR policies.

\section{METHOD}

This research was conducted at a private university in Jambi City, which does not yet have an LMS which involves ten educators in different programs and sciences with regard to teaching management during the implementation of the learning policy of 
learning from home, namely Belajar Dari Rumah (BDR). BDR is a distance learning methods through the network systems. The research approach is descriptive qualitative because the purpose of research is to describe the experience of educators in the context of information sharing related to teaching management during the Covid 19 pandemic, including planning, organizing, implementing, and controlling teaching educators. Research data obtained through observations, interviews, and documentation according to qualitative data collection techniques.

Observations conducted asking general questions regarding teaching management and BDR policies with the purpose to find out the educator's understanding of research topics. The interview addressed on ten educators in private higher education in Jambi city, which have not LMS. Interview did through telephone line. While the documents in this study are form of BDR policy, journals, and other written documents. The collected data carried out analysis based on qualitative research analysis in accordance with research objectives, namely data reduction, data display, and data verification. Furthermore, we used triangulation technique to get the data validity data through source of field data and theory.

\section{RESULT AND DISCUSSION}

Based on the data obtained information that the management of BDR policy carried out by educators at private universities in the city of Jambi who do not have LMS is a re-management of teaching activities through the following stages:

1. Teaching plan

According to them, teaching planning that originally creates for face-to-face teaching transformed into online teaching, especially in learning methods and assignments to students. As stated by educator 1 (E1):

"The first thing I did, of course, was re-plan my method of teaching, considering that learning through the network was my first time."

While educator 4 (E4) states: "for me the BDR policy does not cause having to redesign the planning of the methods I use in teaching, because I myself have implemented this before, only in learning planning before this policy I did alternately, several times studying in classroom and several times in network".

In the teaching plan used by educators in general is the Whatsapp application as Virtual space to replace the classroom, according to the statement of educator 8

(E8) "I prefer to use the WhatsApp application, and form a group according to the class and the subjects that I teach".

The selection of this application based on the agreement of students with the reason that their use is simpler and rested. This is because the application owned by all students without having to install it on their smartphone, and does not consume a lot of internet quota, the internet network needed does not need to be too strong, and it is very easy for students to look back at learning activities at leisure.

In its teaching plan, educators assign one student who is responsible for learning activities through a WhatsApp group. As stated by educator six (E6):

"Because there are several classes that I teach then I assign one student as a guide for learning activities through WhatsApp"

Based on the results of the interview, teaching with BDR policy method generally conducted by educators without any constraints, only need to redesign in the teaching method using one application that used by all students without any obstacles. 
2. Teaching organize

Educators develop teaching accordance with the guidelines for implementing BDR policies, tailored to the teaching plan and learning schedule. The educator appoints one student who is responsible for learning activities through an agreed application.

Educator's ten (E10) stated:

"Teaching in accordance with BDR policy can be carried out by appointing one student representative as coordinator in my teaching activities"

The similar opinions also conveyed by educator seven (E7) with the following statement:

"I am more focused on preparing my teaching time on WhatsApp group by arranging time to explain the material, appointing one class representative in each lecture session to guide the lecture, as well as arranging the possibility to use other applications for my teaching activities, such as the use of a zoom application".

Referring to the results of interviews, teaching is arranged based on lecture schedules, lesson plans, and selecting student representatives to be coordinators of learning activities through virtual room.

3. Teaching act

The implementation of teaching carried by educators in different ways, some do by sharing materials in the form of power points in WhatsApp groups, video materials, voice recordings, and self-employed assignments at each meeting. Educator one (E1) explains that:

"...the implementation of teaching in accordance with the schedule and agreement with students. Usually I start BDR activities by sending a recording of the material for the meeting on the day. of course I open the lecture activities by greeting students, by writing in the chat column and sometimes through voice notes, after greeting and instructing the implementation of activities on the day, I share a recording of the material that I have recorded to be heard by students"

Meanwhile, educator six (E6) and educator nine (E9), respectively stated as follows:

E6: "honestly, the implementation of my teaching with the BDR policy cannot be controlled properly, this is because teaching activities in this way is the first thing for me. Nevertheless, I try to keep up with the number of learning meetings I have made in my teaching plan".

E9: "the implementation of teaching with the method directed in the BDR policy I do in accordance with the teaching plan made, but in the implementation often experienced obstacles where students only read the material without any further reaction".

From the results of interviews related to the teaching act, not all educators carry out effectively. There are still educators who have difficulty in carrying out teaching activities through virtual spaces, because it seems rigid and boring.

4. Teaching control

Teaching activities through virtual space need to control, so that teaching objectives can obtain. Controls in teaching activities accordance with BDR policy conduct throughout the limiting the time of writing attendance lists in chat columns, checking the activeness of students commenting on chat 
columns, submitting voice note questions and appointing specific students whose names are in the list of attendance in the chat column

Educator three (E3) and educator five (E5) express their opinions in order as follows:

E3: "in teaching control that I do to ensure that all students who attend actively in learning activities is to ask questions through voice note and mention the name of the student in question to respond to the question I asked, and sometimes I mention one student's name to respond to the statement submitted by his friend in the group".

E5: "control that I do in teaching activities is limiting the writing of attendance list of BDR activities for approximately twenty minutes of the beginning of lectures".

The E1 and E5 statement are in line with the opinions of other Educators.

Based on the results of the data above, it appears that control in teaching in accordance with BDR policy carried out by educators in the same way that is check the attendance list, ask questions, and limits the time of attendance.

Teaching is an activity aimed at providing opportunities for students to develop all the potentials that exist within them through encouragement or solicitation delivered by the educator. Teaching activities in the form of efforts to develop students' knowledge, skills, and attitudes become critical thinking individuals in a learning environment designed by educators. Teaching is also the interaction of educators and learners regarding one subject in a course through learning activities aimed at achieving the main objectives of language and educational objectives (Kusumaningrum, et al., 2019; Lock, 2017; Teach \& Govahi, 1993; PP Nomor 3, 2020). Teaching activities carried out by educators during the covid 19 pandemic based on BDR policy use online teaching methods as an egfort to overcome the spread of the covid 19 virus. Teaching includes interactive activities between educators and learners, evaluation and reflection activities as a form of teaching activities. This activity for educators in universities who do not have LMS is something new. Therefore, it is necessary to manage the learning activities so that they can run in accordance with the established learning process standards (Clegg, R.S., Komberger, M., \& Pitsi, 2016). Learning activities in higher education based on Regulation of the Minister of Education and Culture No. 3 of 2020 are organized with active learning methods such as group discussions, simulations, case studies, cooperative learning, project-based learning, problem-based learning or other methods that can effectively meet graduate learning achievements.

Teaching through learning activities during the covid pandemic must conform to BDR policies and meet the standards of the educational process in universities, forcing educators to manage effectively. Some private university educators in Jambi City, sharing how to manage teaching during the BDR policy as described below:

1. Teaching plan

Planning is an initial activity carried out by educators regarding what to do, when to do, and who to do in learning activities (Lopes, 2011). In this activity according to educators, the first thing they do is thinking about the methods they use in teaching activities taking into account the condition of the learners. This stage is very important according to educators, so that they can plan what media used during learning in order to meet the learning objectives and process standards set by the government (Lock, 2015; Shaikh, 2010). 
Teaching planning during the pandemic according to educators has not changed the material design, but changes only on the methods, media, assessments, and assignments of learners. Planning of teaching methods in the classroom tailored to the teaching activities in the virtual room based on BDR policy.

Planning for learning media selection tailored to the situation and condition of students, educators only provide a choice of media used during learning activities. Learning media used on teaching based on students agreement.

2. Teaching organize

Teaching activities based on BDR policy are determining methods in teaching activities, establishing learning media, choosing coordinators of learning activities, and determining learning activities. Thus, the preparation of teaching activities is based on the materials submitted, the conditions of the learners and adjusted to the planning made (Shaikh, 2010; Terry, 2009). Organizing in teaching is one of the most important steps according to educators on the continuity of teaching activities based on BDR policy, so that the implementation of learning meets the standards of the process in the form of interactive, holistic, effective, collaborative and students-centered learning through interaction between educators and students and learning resources (PP No. 3 Year 2020).

3. Teaching act

The implementation of teaching is the next stage in the management of teaching conducted by educators (Shaikh, 2010; Terry, 2009). The implementation of teaching is an activity to realize the planning that has made and organized in the learning process. At the implementation stage of teaching, educators have their own patterns in accordance with the materials delivered and the condition of the learners.

The use of WhatsApp group as a medium in teaching is the most widely used media by educators, although there are also educators who use other media as a form of implementation of teaching activities based on BDR policy. In the implementation of teaching activities, educators assign one student as a coordinator in the implementation so that learning objectives and process standards realized.

4. Teaching Control

The last teaching management function is the control function (Lopes, 2011, PP. No. 3 Year 2020; Rhode, J., \& Richter, 2017). Controlling teaching activities with selected methods and media in implementing BDR policy aims to ensure that the established learning objectives can be carried out properly in accordance with the learning concepts and process standards set by the government (Wang, H.C., \& $\mathrm{Hsu}$, 2006). The control is setting the student's attendance schedule, asking questions, and checking the student's attendance. In addition, educators in doing control by pointed out one student to respond or to ask questions.

Stages in the management of teaching educators at private universities in Jambi city, who do not have LMS managed according to their knowledge, skills, and creativity. Teaching management is an art and knowledge owned by everyone with uniqueness based on materials, conditions, and learning situations (Latif, M., \& Latief. S. 2018; Taylor. F.W. 1967). The condition of learners and learning resources is one of the considerations made by educators in implementing BDR policies during the pandemic. 
The main finding of this study that educators at private higher education in Jambi city are able to manage their teaching activities based on Belajar Dari Rumah (BDR) policy fix in Law No. 12 of 2012 on higher education, and the standard of learning process that has been set out in the regulation of the Minister of Cultural Education number 3 of 2020. This shows that without having an LMS as a virtual learning medium, educators can manage their teaching activities well by guided by teaching management functions with using simple application such as Whatsapp. In a line with Kurniasari, Pribowo, \& Putra, (2020), the implementation of this BDR is running quite effective because students are used to it devices so that in their learning access is not has significant problems. The effectiveness of use devices in learning are supported by Firmat \& Rahayu (2020) who explained about the behavior of children and adolescents in using the internet recorded as much as 84 percent of the total all Indonesian people are cellular phone users. As much as 52 percent of all cell phone users these are children and adolescents. This research also found that 98 percent of children and of teens surveyed knew about the internet and 79.5 parent among them are internet users. While other research showed that any lack of communication effectively between teachers and students as well as students with other students lead to the implementation process learn from this house, over time it becomes boring for students (Paluli, 2020; Wardani \& Ayriza, 2020). A few other things too causes the learning process so this house becomes less effective is the existence of complex application constraints or not usually used by students, both teachers and students lack of mastery of online learning media platforms used. There are constraints regarding the evaluation process in online, Mustakim (2020) said that to improve quality online learning during the covid-19 pandemic, then providing learning materials should be delivered concisely minimizes sending material inside long video format to save quota

This research was benefit for educators in managing teaching in virtual spaces so that teaching activities can meet process standards and in accordance with the definition of learning set out in government regulations. Furthermore, the manager of private universities in particular, has LMS as a medium used in learning activities both in the pandemic and normal period. Therefore, that learning activities blended through LMS with models that selected according to the material and discussion of learning.

\section{CONCLUSIONS}

Based on the results and discussions above, the management of educator teaching in private universities in Jambi city who do not have LMS are implemented BDR policies during the pandemic period following the established implementation rules without leaving the meaning of learning and learning process standards that have set out in government regulations. Stages in teaching management consist of teaching planning consists of semester learning plans, methods, and media used. At this stage, educators adjust methods and media in accordance with the direction of BDR policy implementation. Furthermore, teaching organize is to establish methods, choose media, and determine student representatives as coordinators. Then, at the teaching act stage, educators carry out according to what has planned and organized. The last stage is controlling, educators doing by way of time restrictions on filling out the present list, doing randomness, giving questions addressed to one of the students.

\section{ACKNOWLEDGEMENTS}

The researchers express gratitude and appreciation for the trust that has been given by Universitas Nurdin Hamzah Jambi, Indonesia 


\section{AUTHOR CONTRIBUTION STATEMENTS}

First author had contribution for collecting data in this research. Corresponding author was a corresponding person with editor, from submission until publish for this article. Another authors help to improve this research paper before submit to journal.

\section{REFERENCES}

Ali, A.J., \& Camp, R.C. (1995). Teaching management in the Arab world: confronting illusions. International journal of educational management, Vol 9 (2), 10-17. https:// doi.org/10.1108/09513549510082332

Burki, A.L. \& Rau, B. (2017). The research teaching gap in management. Academy of management learning $\mathcal{E}$ education, Vol 9 (1). https:// doi.org/10.5465/amle.9.1.zqr132

Clegg, R.S., Komberger, M., \& Pitsi, S.T. (2016). Managing \& Organization: An introduction to theory and practice. Los Angeles: SAGE. Google Scholar

Eli, H., \& Arntzen, A.A.B. (2013). Facilitating teaching and learning capabilities in social learning management systems: Challenges, issues, and implications for designs. Journal of integrated designs and process science, Vol 17 (1), 17-35. 10.3233/jid-2013-0003

Firman, F., \& Rahayu, S. (2020). Pembelajaran online di tengah pandemi covid-19. Indonesian Journal of Educational Science (IJES), 2(2), 81-89. https:// doi.org/10.31605/ijes.v2i2.659

Goodyear, P. (2015). Teaching as design. Herdsa review of higher education, Vol.2, 2950. Google Scholar

Kotzert, S., \& Eiran, Y. (2012). Learning and teaching with Moodle-based e-learning environments, combining learning skills and content in the field of math and science \& technology. $1^{\text {st }}$ Moodle research conferences, Heraklion, Crete- Greece, September 14-15. Google Scholar

Kusumaningrum, D.E., Sumarsono,R.D., \& Gunawan, I. (2019). Professional ethics and teacher teaching performance: Measurement of teacher empowerment with a soft system methodology approach. International Journal of innovation, creativity, and change, Vol 5 (4). Google Scholar

Kurniasari, A., Pribowo, F. S. P., \& Putra, D. A. (2020). Analisis Efektivitas Pelaksanaan Belajar Dari Rumah (Bdr) Selama Pandemi Covid-19. Jurnal Review Pendidikan Dasar: Jurnal Kajian Pendidikan Dan Hasil Penelitian, 6(3), 246-253. http:/ / dx.doi.org/10.26740/jrpd.v6n3.p246-253

Latif, M., \& Latief. S. (2018). Teori Manajemen Pendidikan. Jakarta: Prenada Media Group.

Lock, A.E. (2017). The epistemological side of teaching management: Teaching through principals. Academy of management learning $\mathcal{E}$ education, Vol 1(2). https:// doi.org/10.5465/amle.2002.8509391

Lopez, S. J. (2011). The highs and lows of student engagement. Phi Delta Kappan, 93(2), 72. Google Scholar

Mingers, J. (2000). What is it to be critical? Teaching a critical approach to management undergraduates. Management Learning, 31(2), 219-237. https:// doi.org/10.1177\%2F1350507600312005

Masi, A. C., \& Winer*, L. R. (2005). A university-wide vision of teaching and learning with information technologies. Innovations in Education and Teaching International, 42(2), 147-155. https:/ / doi.org/10.1080/14703290500062516 
Mustakim, M. (2020). Efektivitas pembelajaran daring menggunakan media online selama pandemi covid-19 pada mata pelajaran matematika. Al asma: Journal of Islamic Education, 2(1), 1-12. https:/ / doi.org/10.24252/asma.v2i1.13646

Palupi, T. N. (2020). Tingkat Stres pada Siswa-Siswi Sekolah Dasar dalam Menjalankan Proses Belajar di Rumah Selama Pandemi Covid-19. Jurnal psikologi pendidikan dan pengembangan sdm, 9(2), 18-29. Google Scholar

Peraturan Menteri Pendidikan dan Kebudayaan Nomor 3 tahun 2020 Tentang Standar Nasional Perguruan Tinggi.

Rhode, J., Richter, S., \& Miller, T. (2017). Designing personalized online teaching professional development through self-assessment. TechTrends, 61(5), 444-451. https:// doi.org/10.1007/s11528-017-0211-3

Shaikh, A. M. (2010). Understanding educational management: A handbook for teachers and the tahught. Pakistan: Google Scholar

Surat Edaran Menteri Pendidikan Kebudayaan No. 4 Tahun 2020 Tentang Kebijakan BDR.

Surat Edaran Sekretaris Jenderal No. 15 Tahun 2020 Tentang Petunjuk Pelaksanaan BDR.

Taylor. F.W. (1967). Principles of scientific management. New York: Herper. Google Schoolar

Teach, R. D., \& Govahi, G. (1993). The role of classroom techniques in teaching management skills. Simulation \& Gaming, 24(4), 429-445. https:// doi.org/10.1177\%2F1046878193244002

Terry. R.G. (2009). Prinsip-prinsip manajemen. Jakarta: Bumi Aksara.

Undang-Undang Nomor 12 tahun 2012 tentang Pendidikan Tinggi.

Wang, H.C., \& Hsu, C.W. (2006). Teaching-material design center: an ontology based system for customizing reusable e-materials. Computers $\mathcal{E}$ education, Vol 46 (4). https:// doi.org/10.1016/j.compedu.2005.09.005

Wardani, A., \& Ayriza, Y. (2020). Analisis kendala orang tua dalam mendampingi anak belajar di rumah pada masa pandemi Covid-19. Jurnal Obsesi: jurnal Pendidikan anak usia dini, 5(1), 772-782. https:/ / doi.org/10.31004/obsesi.v5i1.705

Yueh, P.H., \& Hsu, S. (2018). Designing a learning management system to support instruction. Communication of the ACM, Vol 51 (4). https:// doi.org/10.1145/1330311.1330324

Copyright Holder :

(C) Latief, S., Hendrayani, S., \& Samsudin, S. (2021).

First Publication Right :

(c) IJoASER (International Journal on Advanced Science, Education, and Religion)

This article is under:

CC BY SA 